\title{
Glyphosate Drift Affects ARbuscular MycorRhizal Association IN COFFEE ${ }^{1}$
}

\author{
Deriva de Glyphosate Afeta a Associação Micorrízica Arbuscular em Cafeeiro \\ CARVALHO, F.P. ${ }^{2}$, SOUZA, B.P. ${ }^{2}$, FRANÇA, A.C. ${ }^{3}$, FERREIRA, E.A. ${ }^{3}$, FRANCO, M.H.R. ${ }^{3}$, \\ KASUYA, M.C.M. ${ }^{2}$, and FERREIRA, F.A. ${ }^{2}$
}

\begin{abstract}
Mycorrhizal association promotes better survival and nutrition of colonized seedling on field, and consequently, increasing of productivity. However, the weed management can interfere on this association, due to incorrect use of glyphosate. This work has assessed the effects of glyphosate drift on the growth and nutrition of arabica coffee plants (Catuai Vermelho - IAC 99) colonized with arbuscular mycorrhizal fungi (AMF). The experiment was conducted in 2 x 5 factorial scheme, and included inoculated and non-inoculated plants, and five glyphosate subdoses $\left(0.0,57.6,115.2,230.4\right.$, and $460.8 \mathrm{~g} \mathrm{ha}^{-1}$ of glyphosate), in randomized blocks with five replication. The inoculation was carried during the greenhouse phase of seedlings production with a mixture of Rhizophagus clarus and Gigaspora margarita, and after to transplanting, when the plants had seven pairs of leaves, glyphosate subdoses were applied. The product caused intoxication in up to $60 \%$ of non-inoculated and $45 \%$ on inoculated plants, when the highest dose of $460.8 \mathrm{~g}$ a.e. ha $^{-1}$ was applied. A negative effect was noted on the growth and phosphorus content of coffee plants, this effect increased depending on glyphosate subdose, but regardless of inoculation. Glyphosate drift reduces the growth and nutrition of plants colonized by species of AMF and native fungi, negatively affecting root colonization of plants treated.
\end{abstract}

Keywords: Coffea arabica, glyphosate drift, mycorrhiza, Rhizophagus clarus, Gigaspora margarita.

RESUMO - A associação micorrizica favorece o estabelecimento, a sobrevivência no campo e a nutrição da planta hospedeira, levando por consequência, a maior crescimento e produtividade. Todavia, o manejo de plantas daninhas no cafeeiro pode interferir nessa associação, podendo o emprego incorreto do glyphosate influenciar nesses beneficios da associação. Avaliou-se neste trabalho efeito da deriva do herbicida glyphosate no crescimento e estado nutricional de plantas de café arábica (Catuai Vermelho IAC 99) inoculadas com fungos micorrizicos arbusculares (FMAs). Para isso, utilizou-se esquema fatorial $2 \times 5$, sendo mudas inoculadas ou não inoculadas com FMAs e cinco subdoses de glyphosate $\left(0 ; 57,6 ; 115,2 ; 230,4 ;\right.$ e 460, $8 \mathrm{~g} \mathrm{ha}^{-1}$ de glyphosate), em delineamento de blocos casualizados com cinco repetições. A inoculação foi efetuada na fase de produção de muda, com uma mistura de FMAs, Rhizophagus clarus e Gigaspora margarita; posteriormente ao transplantio, quando as plantas estavam com sete pares de folhas, aplicaram-se as subdoses de glyphosate. O herbicida causou fitointoxicação de até $60 \%$ em plantas não inoculadas e de $45 \% \mathrm{em}$ plantas inoculadas com aplicação da maior dose de 460,8 g e.a. ha ${ }^{-1}$. Verificou-se efeito negativo no crescimento das plantas de café e do teor de fósforo delas com o aumento das doses de glyphosate, independentemente da inoculação. O herbicida reduziu o crescimento de plantas colonizadas pelos FMAs testados, bem como de fungos nativos, afetando negativamente a colonização micorrizica das plantas tratadas com o glyphosate.

Palavras-chave: Coffea arabica, deriva de glyphosate, micorriza, Rhizophagus clarus, Gigaspora margarita .

1 Recebido para publicação em 27.5.2014 e aprovado em 31.7.2014.

2 Universidade Federal de Viçosa, Viçosa, Minas Gerais, Brazil, < felipepaolinelli@yahoo.com.br>; ${ }^{3}$ Universidade Federal dos Vales do Jequitinhonha e Mucuri, Diamantina, Minas Gerais, Brazil. 


\section{INTRODUCTION}

Coffee is significantly relevant for the Brazilian economy, mainly to encourage international currencies, besides to create employment for large numbers of workers. Even though coffee has already gained importance in the Brazilian agribusiness, producers and researchers seek to leverage its culture, to achieve greater sustainability, quality and productivity for the success of their crop production (Miranda et al., 2006). Moreover, coffee production leveraging might be favored by the practice of inoculating microorganisms during the production of seedlings, which can promote greater growth and productivity for plants.

Among these microorganisms, the arbuscular mycorrhizal fungi (AMF) can be highlighted for increasing nutrient absorption, increasing the effective exploitation of soil volume, and transfering much of these nutrients to the host plant, benefiting from its growth, development and, consequently, their vigor and productivity (Moreira \& Siqueira, 2006). Such association also maintains plant roots active for a longer period, protects the plant against pathogens and other stresses in the field, favoring their establishment and survival in the field (Maia et al., 2006).

As mycorrhiza is a compartmentalized biological system (soil, plant and fungus), it is influenced by the environment and by the edaphic factors of each component, which directly or indirectly interfere in the formation and functioning of the association (Smith \& Read, 2008). Such factors include the use of pesticides, such as herbicides, which have a direct impact on culture (Vieira et al., 2007), with few reports of its influence on soil microorganisms, including $\mathrm{AMF}$, and on mycorrhizal association.

Weed management is costly and, if efficient, can result in negative interference on the growth and productivity of coffee, especially on plant life stages, in the implementation period of the crop (Fialho et al. 2011). Chemical control is an option to solve this problem, and glyphosate is the most commonly used herbicide for coffee, due to its efficient control and low cost.
Glyphosate is a total action herbicide; during its spraying, there is a possibility of "accidental drift," which is the dispersion of drops to non-target plants, possibly causing the poisoning of other culture, and several cases have been reported. The intoxication of coffee plants can vary with certain characteristics, such as farming method or plant height (France et al, 2010, 2013), in addition to other possibilities, such as surface soil moisture and leaf age, stage of development and others that will directly influence the absorption and metabolism of the product. In addition, more robust and livelier plants may suitably have a higher ability to withstand the effects of the herbicide.

This study aimed to evaluate the effects of glyphosate drift on the growth and nutritional status of Arabica coffee plants inoculated with AMF.

\section{MATERIAL AND METHODS}

The experiment was conducted in a greenhouse using Coffea arabica Catuaí Vermelho IAC 99. For the production of seedlings, we used previously sterilized seeds with sodium hypochlorite solution $(1 \%)$ and washed with distilled water and sown in autoclaved sand. On the matchstick phase, they were transplanted to bags containing the substrate (consisting of seven portions of sifted soil and three portions of corral manure), fertilized according to Guimarães et al. (1999). Upon transplanting, half of the seedlings were inoculated with species of mycorrhizal fungi (AMF).

A $2 \times 5$ factorial arrangement was adopted, in which the first factor referred to the inoculation or non-inoculation with $\mathrm{AMF}$ and the second referred to five rates of glyphosate in simulated drift.

Treatments were arranged in randomized blocks with four replications. Inoculation was performed at the time of transplanting, half of the plants were inoculated with a mixture of AMF species Gigaspora margarita and Rhizophagus clarus. The inoculation was made by mixing AMF species Gigaspora margarita Rhizophagus Clarus (1: 1), which had about 100 spores per $10 \mathrm{~g}$ of inoculant, which was the amount applied to each bag. 
Underdosing tested included: 0.0; 57.6; 115.2; 230.4; and $460.8 \mathrm{~g} \mathrm{ha}^{-1}$ of glyphosate acid equivalent ( $\mathrm{N}$-phosphonomethyl glycine), corresponding, respectively, to $0,4,8,16$ and $32 \%$ of the dose of $1.440 \mathrm{~g} \mathrm{ha}^{-1}$ from the Roundup Original ${ }^{\circledR}$ formulation of isopropylamine salt. The experimental unit consisted of one coffee plant per pot.

When showing four to five pairs of permanent leaves, the seedlings were transplanted to $20 \mathrm{dm}^{3}$ pots, filled with substrate, formulated with $300 \mathrm{dm}^{3}$ of sieved soil sample and $700 \mathrm{dm}^{3}$ corral manure, fertilized with $2.5 \mathrm{~kg}$ of simple superphosphate and $0.5 \mathrm{~kg}$ potassium chloride.

Soil chemical analysis showed the following results: $\mathrm{pH}$ (water) of 5.3; organic matter content of $1.6 \mathrm{dag} \mathrm{kg}^{-1} ; \mathrm{P}, \mathrm{K}$ and $\mathrm{Ca}$ of $0.2,8$ and $0.5 \mathrm{mg} \mathrm{dm}^{-3}$, respectively; and $\mathrm{Mg}, \mathrm{Al}, \mathrm{H}+\mathrm{Al}$ and $\mathrm{CEC}_{\text {effective }}$ of $0.4,0.3,6.5$ and $1.2 \mathrm{cmol}_{c} \mathrm{dm}^{-3}$, respectively. After the formulation of the substrate, we determined the soil potential of inoculum, which showed 20 spores per $10 \mathrm{~g}$ of soil.

The application of glyphosate was made when plants were on the stage of seven pairs of leaves developed, using a $\mathrm{CO}_{2}$ pressurized backpack sprayer kept on constant pressure of $250 \mathrm{kPa}$, equipped with a double-headed range bar (TT 110 02), spaced $50 \mathrm{~cm}$ apart and applying $200 \mathrm{~L} \mathrm{ha}^{-1}$ of the mixture.

At 0 and 45 days after the application of glyphosate (DAA), height and leaf area were measured. At 45 days, plants were cut at ground level, the stem, leaves and roots were separated apart, and all parts were washed.

To evaluate AMF root colonization in coffee, fresh root system was washed and then sampled, fragments of about $1 \mathrm{~cm}$ in length of thin root were gathered from each plant, to represent the entire root system. Sampled roots were clarified with $\mathrm{KOH}(10 \%)$ and stained with trypan blue in $0.05 \%$ lactoglycerol. Checkered plate technique was used to account for mycorrhizal colonization, by counting each root interception with the lines of the plate, arranged horizontally and vertically at $1 \mathrm{~cm}$ of each other, as colonized or not, and percentage ratio of colonized interceptions was calculated.
Afterwards, leaf area was scanned and subsequently measured using the Digital Determinator Area program.

Subsequently, all material was individually packaged in paper bags and brought to the oven with forced air circulation $\left(60^{\circ} \mathrm{C}\right)$ to constant weight to determine the dry weight of the plant parts. Laboratory analysis of phosphorus was also conducted, using an adjusted vitamin C (Braga \& Defelipo, 1974) method, after the material was crushed and subjected to nitropercloric solubilization.

Data were subjected to analysis of variance, using the $\mathrm{F}$ test $(\mathrm{p} \leq 0.05)$. When interaction was significant, trial was unfolded by employing regression analysis to the evaluation dates. Model selection was based on its significance, biological phenomenon and coefficient of determination.

\section{RESULTS AND DISCUSSION}

All variables showed significant interaction between the factors inoculation and doses of glyphosate, thus, regression analysis was unfolded and executed for the rates of glyphosate applied in inoculated and noninoculated plants.

Younger leaves treated with glyphosate showed chlorosis and narrowing of the leaf blade, which increased with increasing underdosing, regardless of coffee plant being inoculated or not. Chlorosis and narrowing of young leaves, which had expanded after the applying of glyphosate, were also observed in different coffee cultivars after receiving rates of glyphosate (França et al., 2010). The symptom of chlorosis caused by the herbicide may be due to the fact that glyphosate indirectly hinders the synthesis of chlorophyll, as found in soybean plants by Ding et al. (2011). As for the narrowing of the leaf blade, it can result from the inhibition of the phenylalanine, tyrosine and tryptophan aromatic amino acids that are essential for cell division and protein synthesis, causing different leaf growth (Haslam, 1993). The intoxication caused by glyphosate was linear with increasing dose of product applied, increasing in 0.1047 and $0.1356 \%$ of intoxication with each gram increment of herbicide applied in plant inoculated or not with the AMF species R. clarus and G. margarita (Figure 1). 


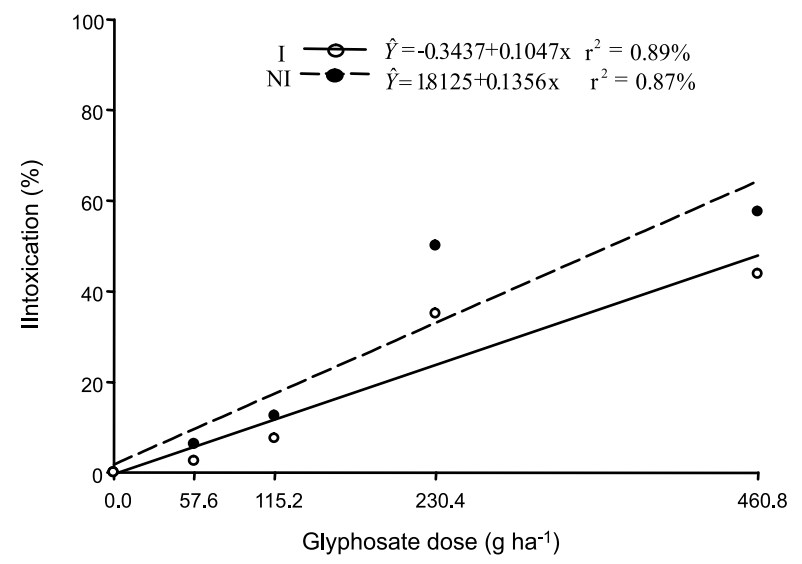

Figure 1 - Intoxication percentage of coffee plants (Catuaí Vermelho IAC 99) inoculated with arbuscular mycorrhizal fungi (Gigaspora margarita and Rhizophagus clarus) (I) and non-inoculated (NI), 45 days after the application of glyphosate rates. (figures expressed in $\%$ compared to control).

A reduction in coffee plant height increment occurred as a function of increasing doses of glyphosate. This behavior followed a continuous decreasing linear trend with increased herbicide dose, resulting in 0.0203 and 0.0062 gram for each gram of herbicide, respectively, for plants inoculated and noninoculated with mycorrhizal fungi (Figure 2A). França et al. (2010, 2013) have found that glyphosate drift has negatively influenced the height increase, as doses were increased for different cultivars of Coffea arabica at 45 days after herbicide application. Glyphosate is a systemic herbicide that, when absorbed, translocates through the plant, following the route of the products of photosynthesis, from the photosynthetically active leaves towards the parts of plants that use these products, establishing a path from source to drain (Caseley \& Coupland, 1985). Thus, the herbicide affects the growing points of the plant, also present in the stem apex, hindering growth in that region, according observed in this work and by França et al. (2010).

There was a smaller increase in leaf area with increasing doses of glyphosate, followed by a linear decrease in the values of inoculated and non-inoculated plants. The inoculated plants showed a decrease of $0.5398 \mathrm{~cm}^{2}$ per gram of glyphosate, and noninoculated, a reduction of $1.3246 \mathrm{~cm}^{2}$ (Figure 2B). Similarly, França et al. (2010) observed a decreasing linear trend for Catucaí and Oeiras cultivars, a decrease of 4.004 and $4.355 \mathrm{~cm}^{2}$, respectively, for each g of herbicide applied.

Root dry matter was affected by glyphosate, and increasing doses caused lower values for this variable (Figure 3A). With the application of the highest dose of glyphosate, root dry matter showed reductions of 18 and $50 \%$ in inoculated and non-inoculated plants, respectively. Due to the fact that the internal movement of glyphosate in the plant follows the same direction of photoassimilates, towards the growing points, where these products will be used, glyphosate can achieve root tips. In the initial phase of coffee plant growth, the root system is in rapid expansion
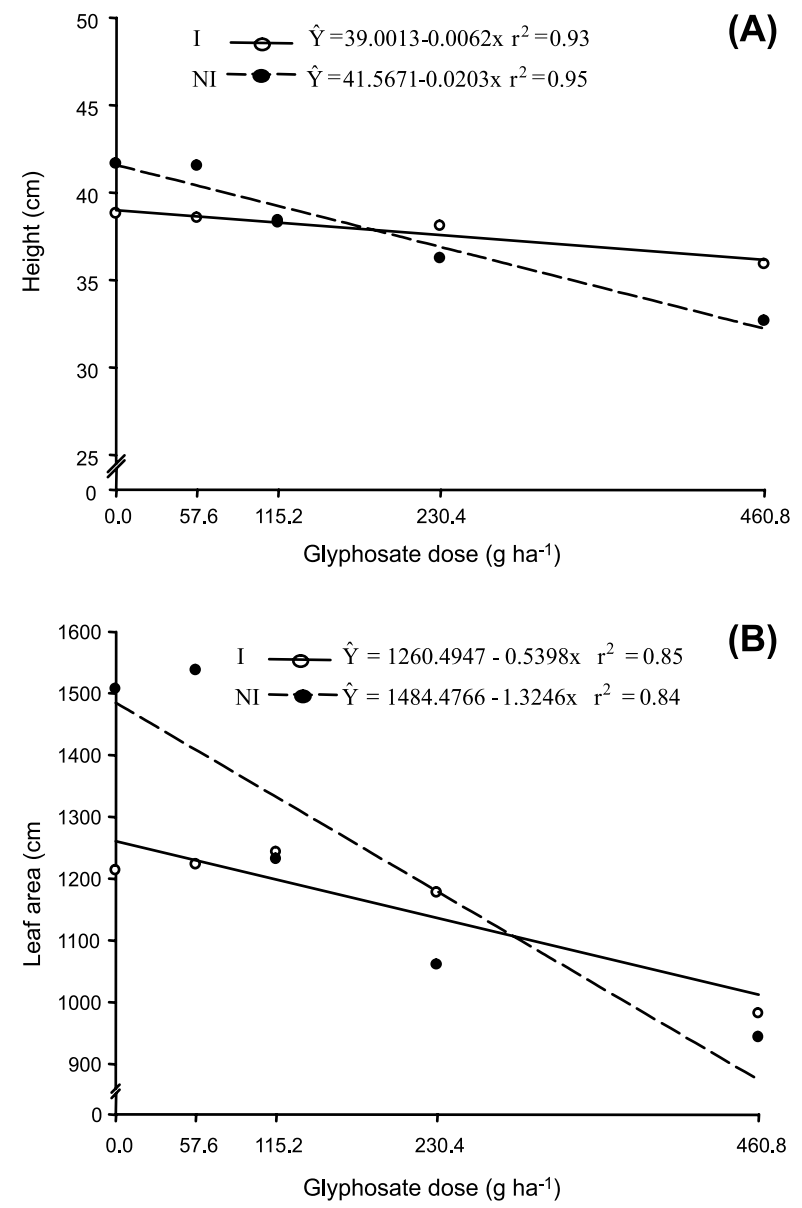

Figure 2 - Height (A) and leaf area (B) of coffee plants (Catuaí Vermelho IAC 99) inoculated with arbuscular mycorrhizal fungi (Gigaspora margarita and Rhizophagus clarus) (I) and non-inoculated (NI), 45 days after the application of glyphosate rates. 

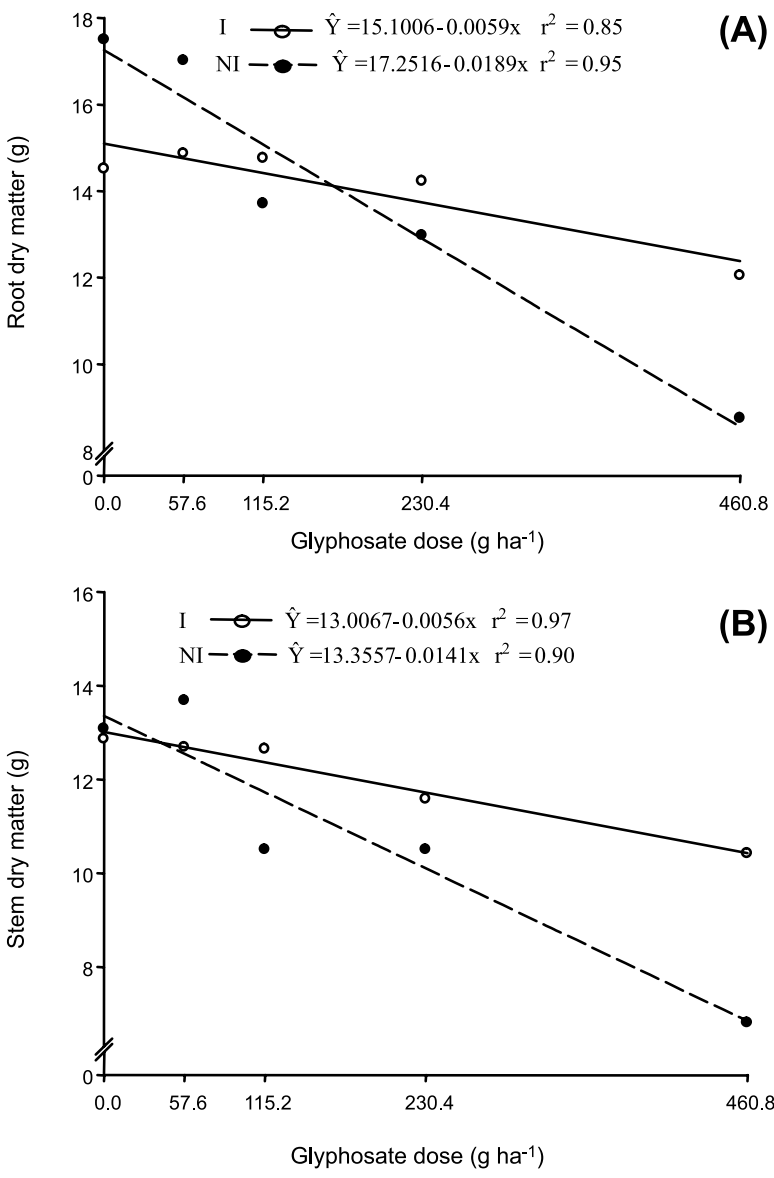

Figure 3 - Root (a) and stem (b) dry matter of coffee plants (Catuaí Vermelho IAC 99) inoculated with arbuscular mycorrhizal fungi (Gigaspora margarita and Rhizophagus clarus) (I) and non-inoculated (NI), 45 days after the application of glyphosate rates, simulating drift.

and high activity of cell division, thus requiring from aromatic amino acids that are inhibited by glyphosate. Tuffi Santos et al. (2005) observed the presence of glyphosate in the root system through root browning, 15 days after glyphosate application in brachiaria plants, indicating that root tissues were necrotic.

Stem dry matter decreased with increasing dose of the herbicide, following a negative linear trend. With the highest dose of glyphosate, stem dry matter showed a reduction in the accumulation of 20 and $49 \%$ in inoculated and non-inoculated plants, respectively. These values corroborate those reported by França et al. (2010), who found a reduction of $23 \%$ in the dry weight of coffee plant shoots after subjected to $460.8 \mathrm{~g}$ of glyphosate per hectare.
The inoculated plants showed a linear decrease in leaf dry matter, decreasing by $2.7 \%$ its value for each $50 \mathrm{~g}$ of glyphosate applied, while non-inoculated plants had a positive quadratic polynomial trend (Figure 4A). França et al. (2013) observed the same behavior of leaf dry matter, following positive polynomial trend with increased dose of glyphosate in Acaiá. This herbicide can interfere with the uptake of carbon, which helps reduce the accumulation of dry matter, as shown by plants exposed to this product (Figure 4B). Total dry matter showed less accumulation of matter for inoculated or not plants, with a reduction of around 20 and $49 \%$ of inoculated and noninoculated plants, respectively (Figure 4B).

By analyzing the leaf phosphorus content, it was found that, regardless of inoculation,
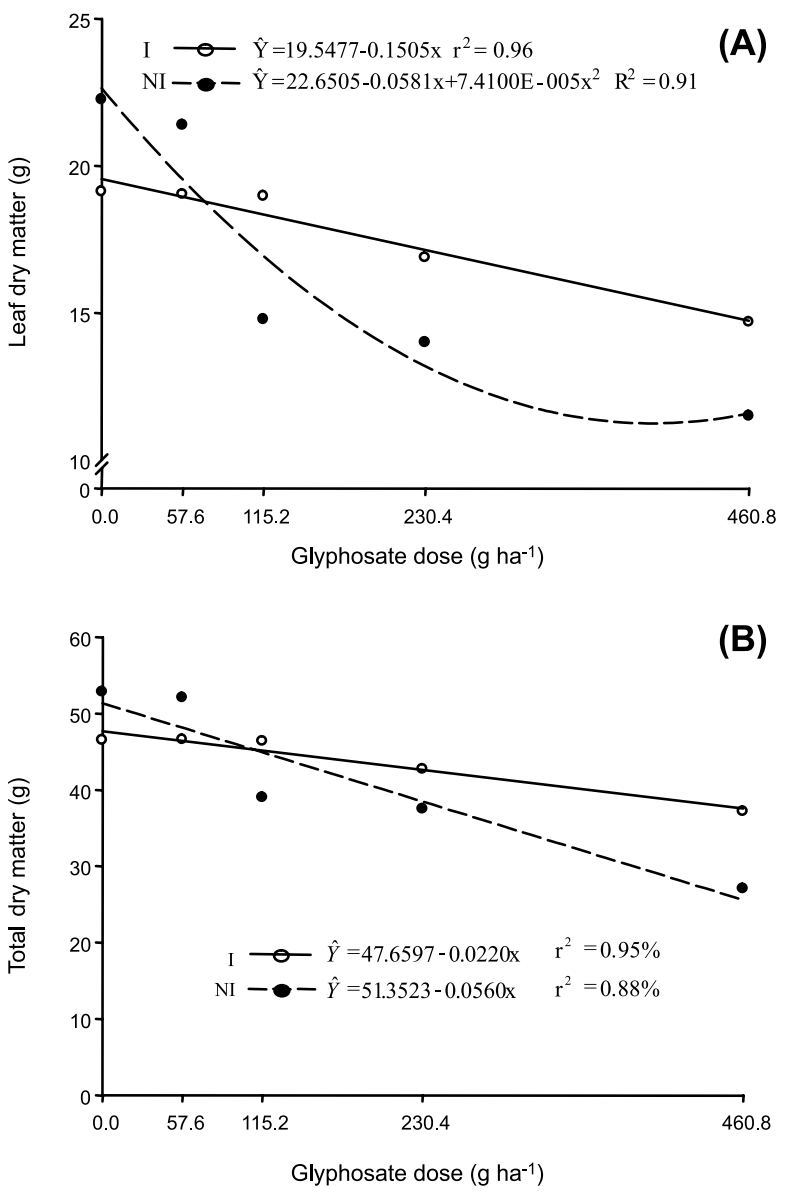

Figure 4 - Leaf (a) and total (b) dry matter of coffee plants (Catuaí Vermelho IAC 99) inoculated with arbuscular mycorrhizal fungi (Gigaspora margarita and Rhizophagus clarus) (I) and non-inoculated (NI), 45 days after the application of glyphosate rates.

Planta Daninha, Viçosa-MG, v. 32, n. 4, p. 783-789, 2014 
there was a decrease in values with increasing doses of glyphosate. Increasing doses linearly reduced nutrient content of phosphorus 0.5 and $0.6 \mathrm{mg} \mathrm{kg}^{-1}$ per gram of herbicide for inoculated and non-inoculated plants, respectively (Figure 5). It is known that inoculation, at the time of transplanting of seedlings at the "matchstick" stage, increases the phosphorus content of those seedlings (Andrade et al, 2010.); however, glyphosate interferes with coffee nutrition, providing lower phosphorus content in the treated plant, as found for inoculated and non-inoculated (Figure 4) plants. The absorption may have been affected by increasing doses of glyphosate, causing damage to the structure of the plant, including the root, thereby reducing their ability to absorb nutrients.

Plants inoculated with the selected fungi showed linear behavior for reducing colonization with increasing dose. For noninoculated plants, with roots colonized only by AMF originated from the soil used, colonization had quadratic behavior, with the dose of $301.0 \mathrm{~g}$ of glyphosate they had the lowest colonization; from this dose, the native AMF began to stabilize and even showed signs of recovery (Figure 6). Glyphosate can affect colonization by translocating into the plant until reaching the root system or directly on the AMF, which is also present in the soil, despite their low activity. Such capability was proven by the negative effects of glyphosate directly in AMF

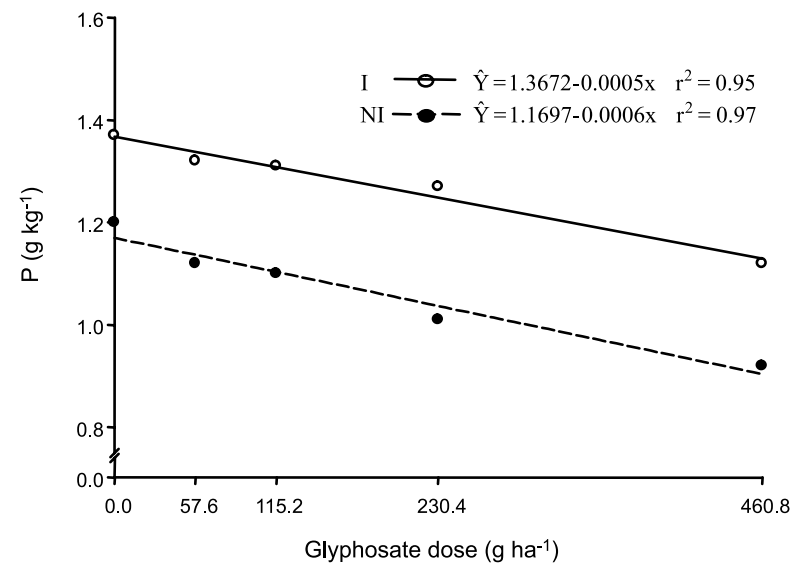

Figure 5 - Phosphorus levels of coffee plants (Catuaí Vermelho IAC 99) inoculated with arbuscular mycorrhizal fungi (Gigaspora margarita and Rhizophagus clarus) (I) and noninoculated (NI), in different glyphosate rates.

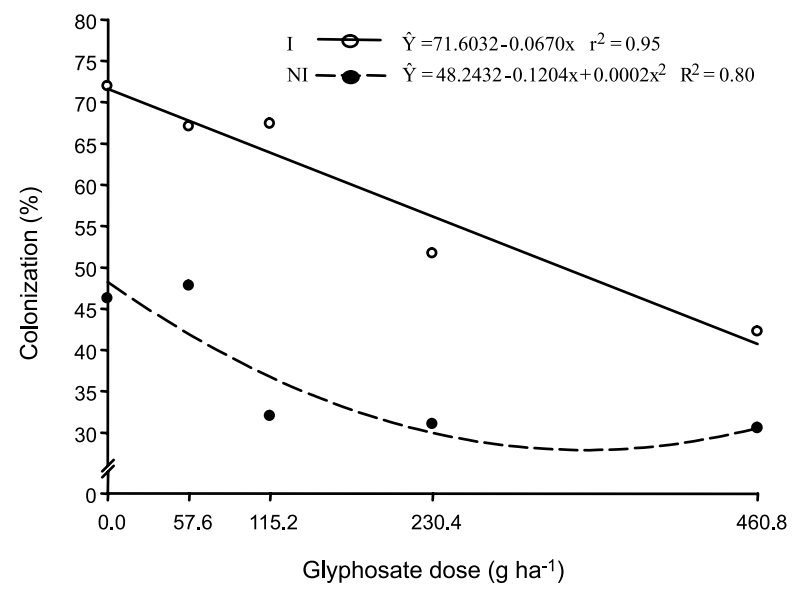

Figure 6 - Colonization of coffee plants (Catuaí Vermelho IAC 99) inoculated with arbuscular mycorrhizal fungi (Gigaspora margarita and Rhizophagus clarus) (I) and non-inoculated (NI), in different glyphosate rates.

spores belonging to the soil (Druille et al., 2013). These authors observed reduction of spore germination and colonization of plants grown in inoculum previously submitted to the glyphosate. It is noteworthy that other methods of weed control may end in more aggressive results to the population of $\mathrm{AMF}$, for instance, soil disturbance (Brito et al., 2013), also widely used before the planting of coffee.

According to our results, subdoses of glyphosate negatively affect coffee plants, regardless of colonization by fungi $R$. clarus and G. margarita or native AMF; Plants colonized by $R$. clarus and $G$. margarita are less affected with increasing doses. Glyphosate drift affects plant-AMF interaction, and it can act directly on the fungus or through sprayed plants. Thus, one should avoid the application of glyphosate or be aware of the cares to be taken during its spraying in coffee plantations, where mycorrhizal association should be fully beneficial.

\section{ACKNOWLEDGMENTS}

We give thanks to the Coordenação de Aperfeiçoamento de Pessoal de Nivel Superior, CAPES, and to the National Council for Scientific and Technological Development CNPq, and the Foundation of Reseacrh Support from the state of Minas Gerais, FAPEMIG, for granting scholarship and funds for the development of this work. 


\section{LITERATURE CITED}

ANDRADE, S. A. L.; SILVEIRA, A. P. D.; MAZZAFERA, P. Arbuscular mycorrhiza alters metal uptake and the physiological response of Coffea arabica seedlings to increasing $\mathrm{Zn}$ and $\mathrm{Cu}$ concentrations in soil. Sci. Total Environ., v. 408, p. 5381-5391, 2010.

BRAGA, J. M.; DEFELLIPO, B. V. Determinação espectrofotométrica de $\mathrm{P}$ em extratos de solo e material vegetal. R. Ceres, v. 21, n. 113, p. 73-85, 1974.

BRITO, I.; CARVALHO, M.; GOSS, M. J. Soil and weed management for enhancing arbuscular mycorrhiza colonization of wheat. Soil Use Manag., v. 29, n. 4, p. 540-546, 2013.

CASELEY, J. C.; COUPLAND, D. Environmental and plant factors affecting glyphosate uptake movement and acidity. In: GROSSBARD, E.; ATKINSON, D. A. The herbicide glyphosate. London: Butterworths, 1985. p. $92-123$.

DING, W. et al. Physiological responses of glyphosateresistant and glyphosate-sensitive soybean to aminomethylphosphonic acid, a metabolite of glyphosate. Chemosphere, v. 83, n. 4, p. 593-598, 2011.

DRUILLE, M. et al. Glyphosate reduces spore viability and root colonization of arbuscular mycorrhizal fungi. Appl. Soil Ecol., v. 64, n. 1, p. 99-103, 2013.

FIALHO, C. M. T. et al. Interferência de plantas daninhas sobre o crescimento inicial de Coffea arabica.

Planta Daninha, v. 29, n. 1, p. 137-147, 2011.

FRANÇA, A. C. et al. Crescimento de cultivares de café arábica submetidos a doses do glyphosate. Planta Daninha, v. 28, n. 3, p. 599-607, 2010.
FRANCA, A. C. et al. Deriva simulada do glyphosate em cultivares de café Acaiá e Catucaí. Planta Daninha, v. 31, n. 2, p. 443-451, 2013.

GUIMARÃES, P. T. G. et al. Cafeeiro. In: RIBEIRO, A. C.; GUIMARÃES, P. T. G.; ALVAREZ, V. V. H. (Ed.).

Recomendações para uso de corretivos e fertilizantes em Minas Gerais: $5^{\mathrm{a}}$ aproximação. Viçosa, MG: Comissão de Fertilidade do Solo do Estado de Minas Gerais, 1999. p. 289-302.

HASLAM, E. Shikimic acid: metabolism and metabolites. Chinchester: John Wiley, 1993. 392 p.

MAIA, L. C.; SILVEIRA, N. S. S.; CAVALCANTE, U. M. T. Interaction between arbuscular mycorrhizal fungi and root pathogens. In: RAI, M. K. (Org.). Handbook of microbial biofertilizers. New York: The Haworth, 2006. p. 325-352.

MIRANDA, G. R. B. et al. Formação de mudas de cafeeiro em substratos oriundos de diferentes métodos de desinfestação. Bragantia, v. 65, n. 2, p. 303-307, 2006.

MOREIRA, F. M. S.; SIQUEIRA, J. O. Microbiologia e bioquímica do solo. 2.ed. Lavras: Universidade Federal de Lavras, 2006. 729 p.

SMITH, S. E.; READ, D. J. Mycorrhizal symbiosis. 3.ed. London: Academic Press, 2008. 803 p.

TUFFI SANTOS, L. D. et al. Exsudação radicular do glyphosate por Brachiaria decumbens e seus efeitos em plantas de eucalipto e na respiração microbiana do solo. Planta Daninha, v. 23, n. 1, p. 143-152, 2005.

VIEIRA, R. F.; SILVA, C. M. M. S.; SILVEIRA, A. P. D. Soil microbial biomass $\mathrm{C}$ and symbiotic processes associated with soybean after sulfentrazone herbicide application. Plant Soil, v. 300, n. 1, p. 95-103, 2007. 